Shulgin, Vladimir \& Pashynsky, Volodymyr (2019) Osoblyvosti realizatsiyi «deokupatsiynoho zakonodavstva» Ukrayiny $\mathrm{v}$ umovakh provedennya operatsiyi ob"yednanykh syl [Features of realization of «de-occupation legislation» of Ukraine in conditions of the operation of the united forces]. Social development \& Security. 9(4), 3 - 20. DOI: http://doi.org/10.33445/sds.2019.9.4.1

\title{
Особливості реалізації «деокупаційного законодавства» України в умовах проведення операції об'сднаних сил
}

\author{
Володимир Шульгін *, Володимир Пашинський ** \\ * Військовий інститут Київського національного університету імені Тараса Шевченка, \\ вул. Ломоносова, 81, м. Київ, 03022, Украӥна, \\ e-mail:vshulgin@ukr.net, \\ к.ю.H., \\ дочент кафедри правового забезпечення факультету фінансів і права.
}

** Національний університет оборони Украӥни імені Івана Черняховського, проспект Повітрофлотський, 28, м. Київ-049, 03049, Украӥна,

e-mail:vpash64@ukr.net,

к.ю.н.,

дочент кафедри правового забезпечення.

$\begin{array}{ll}\text { open_facess } & \begin{array}{l}\text { Анотація: У статті аналізуються теоретико-правові, } \\ \text { законотворчі та нормотворчі аспекти ефективності юридичного }\end{array} \\ \text { Article history: } & \text { механізму реалізації «деокупаційного законодавства»України } \\ \text { Received: June, 2019 } & \text { особливого періоду. З’ясовано, що стартовий законодавчо- } \\ \text { 1st Revision: July, 2019 } & \text { нормативний блок містить окремі деструктивні юридичні } \\ \text { Accepted: August, 2019 } & \text { конструкції, які здатні деформувати підзаконний (військово- } \\ \text { удк 340.132 } & \text { відомчий) рівень процесу реалізації військового законодавства } \\ \text { Запропоновано шляхи нейтралізації деструктивних (формальних, дублюючих, декларативних, } \\ \text { колізійних) юридичних конструкцій з метою оптимізації дієвого, військово-силового та } \\ \text { організаційно-правового механізму повернення тимчасово окупованих територій на Сході } \\ \text { України. }\end{array}$

Ключові слова: деокупаційне законодавство України, особливий період, операція об'єднаних сил, правовий режим операції об'єднаних сил, реалізація військового законодавства України, колізії та прогалини, прийоми законодавчої техніки, ефективність юридичних механізмів реалізації деокупаційного законодавства.

\section{1. Формулювання проблеми}

Стартовим нормативним блоком національного «деокупаційного законодавства» на Сході України та правовою підставою переформатування антитерористичної операції (далі - АТО) на операцію об'єднаних сил (далі OOC) став рамковий Закон України «Про особливості державної політики із забезпечення державного суверенітету України на тимчасово окупованих територіях у Донецькій та Луганській областях» (далі - Закон), який набрав чинності з 24.02.2018 р. [1].

У теоретико-правовому контексті Закон утворює (в окремих моментах «декларує» та «компілює») надзвичайно складний та комплексний юридичний 
механізм реалізації його нормативних приписів. Для Збройних Сил України (далі - 3С України), інших складових сил оборони - надзвичайний, особливоспецифічний процес легітимації їх державно-вутрішньої функції у формі ООС як оборонно-деокупаційної військової операції на території власної держави.

3С України в умовах смертельної небезпеки, вперше у своїй новітній історії як суверенної і незалежної, демократичної держави залучаються у якості базової, керуючої, консолідовано-мілітарної та парамілітарної структури у здійсненні комплексу конституційно-правових, оборонно-безпекових, міжвідомчих збройних заходів (завдань) щодо збереження державності та відновлення територіальної цілісності України, які унормовані як забезпечення національної безпеки і оборони, відсічі $і$ стримування збройної агресії Російської Федерації (далі - РФ) у Донецькій та Луганській областях [1].

Правовою підставою для відсічі $i$ стримування збройної агресї РФ та відновлення територіальної иүлісності України визначається Конституція України, законодавство України та статті 51 Статуту Організації Об'єднаних Націй (далі - ООН) (ст. 11 Закону) [1].

Введення правового режиму ООС як складової частини комплексу спеціальних військових і організаційно-правових заходів та засобів загального правового режиму «деокупації» окремих районів Донецької та Луганської областей України актуалізує проблематику виявлення та нейтралізації деструктивних юридичних конструкцій, які закладені у Законі або можуть бути створені (втілені) через систему підзаконних механізмів його реалізації (військово-відомчих і міжвідомчих) в умовах проведення ООС, до складу яких входять міжвидові та міжвідомчі угрупування військ (сил), особливим завданням яких є захист прав, свобод і законних інтересів громадян України на тимчасово окупованих територіях внаслідок збройної агресії РФ.

\section{2 Аналіз останніх досліджень та публікацій}

Проблематику якості законодавчого та адміністративно-правового забезпечення національної безпеки держави та іiі складових (зокрема в умовах війни на Сході України та окупації частини іiі території у наслідок збройної агресії з боку РФ з 2014 р.) досліджували вітчизняні вчені: О.В. Агапова [2], I.M. Коропатнік [3], В.Й. Пашинський [4], І.С. Руснак [5], Ф.В. Саганюк [6], В.В. Сокуренко [7]. Але теоретико-правові, законотворчі, відомчі нормотворчі особливості юридичного механізму реалізації приписів «деокупаційного законодавства» України в умовах проведення ООС ще не були предметом наукового дослідження.

\section{3. Постановка завдання}

3 огляду на вищезазначене, ми маємо на меті здійснити теоретико-правовий та прикладний аналіз зазначеного Закону, виявити проблемні аспекти його якості (законодавчої техніки), юридичних механізмів реалізації (матеріальних та процедурних) його змістовних норм та окремих актів системи військового 
законодавства України (законодавства у сфері безпеки і оборони), пов'язаних із процесом втілення в життя «особливих» нормативно-правових приписів Закону у військово-оборонну та цивільно-військову сфери суспільних відносин на тимчасово-окупованих територіях України.

Греков А., ще на початку XX ст. наголошував, що армія є озброєнна сила держави, яка забезпечена всіма технічними засобами для найбільш повного здійснення власне функції сили, представляє орган держави, його заклад, який виконує свої спеціальні завдання в її діяльності. Але правовий характер повинен пронизувати всю діяльність армії при виконанні нею своїх державних функцій. Армія є таким же правовим закладом сучасної держави, як і всі інші його органи i роль іiі в житті останньої зберігає свій основний характер при будь-якій обстановці, що переживається державою [8, с. 229-231].

\section{2. Виклад основного матеріалу}

Здійснений нами аналіз технічної якості Закону свідчить про його певну декларативно-політичну доцільність (відсутній правовий механізм повернення тимчасово окупованих територій), прагматично-компіляційну оптимальність.

До того ж, не зважаючи на його невідкладність, при підготовці до першого читання проект Закону не пройшов обов'язкової наукової експертизи, практичної апробації та жодного системного наукового дослідження.

Структурно Закон не містить розділів, зокрема розділу щодо контролю та відповідальності за його порушення, визначень основних термінів (понятійнокатегоріального апарату), складається не типово із надмірно розгорнутої преамбули (19 абзаців, які змістовно-характерні для міжнародних договорів та частина яких не відповідає предмету правового регулювання Закону (посилання на Автономну республіку Крим та місто Севастополь, як і сама його назва); не цілком узгоджених між собою приписів 37 частин 13 статей, із яких 12 статей не мають назв; 33 пунктів; 8 підпунктів; «Прикінцевих та перехідних положень», які одночасно є назвою статті 13 Закону.

Теоретико-правовий аналіз основної нормативної частини змісту Закону дає можливість виокремити матеріально-процедурний механізм його реалізації, який передбачає необхідність прийняття деякої сукупності актів на рівні підзаконних нормативно-правових та піднормативних актів (актів застосування), зокрема

Президента України щодо: визначення меж та переліку районів, міст, селищ i сіл, частин їх територій, тимчасово окупованих у Донецькій та Луганській областях (частина друга ст. 1 Закону); встановлення факту остаточного виведення та повної відсутності всіх збройних формувань РФ у Донецькій та Луганській областях (частина третя статті 7 Закону); призначення Командувача об’єднаних сил за поданням начальника ГШ - ГК ЗС України;

Кабінету Міністрів України щодо: утворення міжвідомчого координаційного органу з метою узагальнення правової позиції держави у питанні відсічі і стримування збройної агресії РФ та підготовки консолідованої претензії України до РФ щодо реалізації їі міжнародно-правової відповідальності за 
збройну агресію проти України (частина четверта ст. 6 Закону); визначення Порядку в’ізду осіб, переміщення товарів на тимчасово окуповані території у Донецькій та Луганській областях і виїзду осіб, переміщення товарів із таких територій (частина третя ст. 12);

Верховного Головнокомандувача ЗС України щодо: визначення початку та завершення заходів із забезпечення національної безпеки і оборони, відсічі i стримування збройної агресії РФ у Донецькій та Луганській областях (окремі рішення) (ст. 8 Закону); затвердження Положення про Об'єднаний оперативний штаб ЗС України, яке визначає зокрема повноваження Командувача об'єднаних сил (частина третя ст. 9 Закону);

Начальника ГШ-ГК ЗС України щодо: визначення меж зон безпеки, прилеглих до району бойових дій (за поданням Командувача об'єднаних сил) (пункт 2 частини першої ст. 8 Закону).

Iз загального числа приписів, у преамбулі та 8 бланкетних частинах відповідних статей Закону закріплено обов'язкове дотримання матеріальних та процесуальних процедур (за аналогією із антитерористичною операцією), встановлених приписами інших нормативно-правових актів на рівні Конституції України, міжнародних договорів, статутів міжнародних організацій, процесуальних кодексів України, законів України, зокрема:

Статуту OOH; IV Гаазької конвенції про закони і звичаї війни на суходолі та додатка до неї: Положення про закони і звичаї війни на суходолі від 18.10.1907, Женевської конвенції про захист цивільного населення під час війни від 12.08.1949 та Додаткового протоколу до Женевських конвенцій від 12.08.1949, що стосується захисту жертв міжнародних збройних конфліктів (Протокол I), від 08.06.1977; Меморандуму про гарантії безпеки у зв’язку 3 приєднанням України до Договору про нерозповсюдження ядерної зброї від 05.12.1994; Договору про дружбу, співробітництво і партнерство між Україною і РФ від 31.05.1997; Резолюції Генеральної Асамблеї Організації ООН «Про територіальну цілісність України» від 27.03.2014 № 68/262; Заяви Верховної Ради України «Про відступ України від окремих зобов’язань, визначених Міжнародним пактом про громадянські і політичні права та Конвенцією про захист прав і основоположних свобод», схваленої Постановою Верховної Ради України від 21.05.2015 № 462-VIII; законів України «Про забезпечення прав і свобод громадян та правовий режим на тимчасово окупованій території України», «Про здійснення правосуддя та кримінального провадження у зв’язку з проведенням АТО».

Об’єднані однією статтею «Прикінцеві та перехідні положення» містять 7 пунктів, що використовують з метою реалізації Закону такі прийоми (правила, засоби) законодавчої техніки (нормотворчості) як:

промульгація - санкціонування главою держави, підписання, публічне офіційне оприлюднення із зазначенням терміну набрання чинності Закону;

презумпція - схвалення Верховною Радою України рішення Президента України про використання Збройних Сил Украӥни та інших утворених відповідно до законів України військових формувань для відсічі і стримування збройної агресії РФ у Донецькій та Луганській областях і забезпечення державного 
суверенітету України на тимчасово окупованих територіях у Донецькій та Луганській областях у разі «схвалення» цього Закону законодавчим органом влади України та набрання ним чинності навіть при матеріальній відсутності конкретно-визначеного рішення Президента України як акту правозастосування Верховного Головнокомандувача ЗС України;

дія Закону у просторі - «у межах міжнародно-визнаного державного кордону України», але в умовах недемаркованості лінії державного кордону України з РФ;

законодавча нормативно-правова узгодженість - (приведення інших законів України у відповідність із цим Законом), зокрема шляхом внесення змін та доповнень до 1 кодифікованого акту на рівні закону України та 7 законів України: Цивільного процесуального кодексу України, законів України «Про статус ветеранів війни, гарантії їх соціального захисту» (надання учасникам ООС статусу учасника бойових дій); «Про місцеве самоврядування в Україні»; «Про військово-цивільні адміністрації»; «Про правовий режим воєнного стану»; «Про забезпечення прав i свобод громадян та правовий режим на тимчасово окупованій території України»; «Про судовий збір»; «Про боротьбу 3 тероризмом» (АТО може здійснюватися одночасно із ООС та/або в умовах запровадження воєнного чи надзвичайного стану);

аналогія закону - (окремі особливості діяльності переміщених з тимчасово окупованої території ВНЗ та наукових установ регулюються статтями 2 та 5-1 Закону України «Про тимчасові заходи на період проведення антитерористичної операції»);

тимчасове делеговане (дискретне) правозастосування - «до моменту прийняття Кабінетом Міністрів України будь-яких рішень щзодо застосування норм цзього Закону діють акти Кабінету Міністрів України, а також обмеження, введені в дію рішеннями Президента України»;

підзаконна «формальна» системна нормотворчість - (Кабінету Міністрів України у місячний строк з дня набрання чинності цим Законом доручено (деюре до 26.03.2018, а де-факто не можливо) привести свої нормативно-правові акти у відповідність із цим Законом);

урядовий надвідомчий контроль та «формальне» забезпечення системної підзаконно-відомчої та міжвідомчої нормативно-правової узгодженості (Кабінету Міністрів України у місячний строк (не реальний строк) 3 дня набрання чинності цим Законом забезпечити приведення міністерствами та іншими центральними органами виконавчої влади їх нормативно-правових актів у відповідність із цим Законом).

Слід додати, що у «Прикінцевих та перехідних положеннях» Закону відсутній «Перелік законодавчих актів про визнання їх такими, що втрачають чинність у зв'язку із набранням чинності цим Законом», що безумовно ускладнило ефективність нормотворчої діяльності з метою його реалізації.

Таким чином, створено певну («заформалізовану») інтегровану модель (програму, порядок, послідовність, алгоритм) матеріально-процедурного механізму реалізації нормативних приписів такого надзвичайно важливого для безпеки держави Закону. 
3 метою «належної» організації нормотворчої складової процесу реалізації Закону протокольним рішенням Уряду лише 21.03.2018 за № 10 схвалено План організації підготовки проектів актів, необхідних для забезпечення реалізації Закону. Але відповідно до Закону Уряду України необхідно було вже до 26.03.2018 привести свої нормативно-правові акти і забезпечити приведення міністерствами та іншими центральними органами виконавчої влади їх нормативно-правових актів у відповідність із цим Законом.

Про значний обсяг військово-відомчої нормотворчості вказує Ю. Бобров, який зазначає, що у Міноборони та Генштабі 9 робочих груп відпрацьовували питання, пов’язані з реалізацією Закону: застосування ЗС України, матеріальнотехнічне забезпечення, волонтерська діяльність, соціальний захист та правовий статус учасника бойових дій, медичне забезпечення та реабілітація, грошове забезпечення та фінансування, забезпечення житлом, стратегічні комунікації, розробка Положення про Об’єднаний оперативний штаб, повноваження цього штабу, повноваження Командувача операцією об'єднаних сил, повноваження тих сил та засобів, які будуть залучені до їі виконання, повноваження та порядок залучення інших правоохоронних органів та органів влади [9].

За твердженням Ю. Боброва всього цей Закон вимагав внесення змін до 78 нормативно-правових актів (на рівні законів, наказів Міноборони, Генштабу, інших міністерств, відомств); розробки великої кількості нових нормативноправових актів. Але він твердо «переконаний, що з реалізацією цього Закону на тимчасово окупованих територіях Донецької та Луганської областей вони будуть визволені. Виконання цього Закону також дасть змогу Україні повернути тимчасово окупований Крим» [10].

Але АР Крим у складі України не є предметом правового регулювання зазначеного Закону, а у п. 3 його «Прикінцевих та перехідних положеннях» зазначено, що «Закон діє без шкоди для невіддільного суверенного права України на тимчасово окуповану РФ територію АР Крим та м. Севастополя та заходів, спрямованих на відновлення територіальної цілісності України у межах $\dddot{\imath}$ міжнародно визнаного державного кордону» [1].

Матіос А. В. менш оптимістичний з цього питання та справедливо зауважує, що «політична вимога врешті змусила законотворців назвати біле білим, а чорне - чорним: на Росію, офіційно визнану країною-агресором і окупантом, покладено всю юридичну та матеріальну відповідальність за те, що відбувається на окупованій частині Донбасу». Але законодавча спроба зафіксувати статус неконтрольованих тимчасово окупованих територій, сам факт російської агресії на території України й водночас - відсутність прописаної норми Закону щодо своєчасного правового реагування, притягнення до відповідальності причетних до вчинення тяжких злочинів на території Луганської та Донецької областей після їх звільнення та повернення у правове поле України, перетворює цей Закон на біполярний гібрид. Наразі ані цивільні слідчі, ані цивільні прокурори, ані судді не можуть дати об'єктивну правову оцінку діям військових та демобілізованих, які вчинили правопорушення. На жаль, у військової прокуратури не лишилося жодних інструментів примусу бюрократичної 
машини, аби спонукати їі до реального захисту військових від наслідків війни в державі [11].

Від початку проведення ООС за 2018 р. видано 97 наказів на виплату грошових винагород в ООС на загальну суму 22,5 млн. грн. 3 них понад 1,5 млн. грн виплачена за знищення ворожої техніки, понад 17 млн. - за участь у бойових діях та більше 2,8 млн. грн - за виконання бойових завдань [12].

Таким чином стан ефективності нормотворчого блоку в процесі реалізації Закону в умовах ООС, зокрема в аспекті діяльності 3С України, через рік після його прийняття (у хронологічній послідовності), орієнтовно виглядає так.

Указом Президента України від 19.05.2018 уведено в дію рішення РНБО України «Про припинення дії для України окремих міжнародних договорів, укладених у рамках Співдружності Незалежних Держав» [13].

Наказом Командувача об’єднаними силами від 22.04.2018 № 18-дск затверджено Положення про групу юридичного радника Об'єднаного командного пункту об'єднаних сил - структурного підрозділу Об'єднаного командного пункту об'єднаних сил (далі - ОКПОС), який призначений для організації правового забезпечення ООС, реалізації законодавства у військовій сфері, вимог норм МГП під час ведення ООС ЗС України [14].

Розпорядженням ООШ ЗС України від 26.04.2018 № 313/ОКПОС/127 головам Донецької обласної військово-цивільної та Луганської обласної військово-цивільної адміністрацій доведено особливий порядок («особливий правовий режим»), що діє у зонах безпеки та районі бойових дій із оголошенням ВГК ЗС України наказу про початок проведення ООС [15].

Наказом ВГК ЗС України від 30.04.2018 № 3дск-оп з 14.0030 квітня 2018 року за спеціальним планом розпочато ООС [16].

Наказами Міноборони України:

від 12.06.2018 № 268 уточнена_з 01.05.2018 назва Інструкції про розміри i порядок виплати винагороди військовослужбовцям 3С України та ДССТ за безпосередню участь у воєнних конфліктах, в заходах ООС ma АТО, інших заходах в умовах особливого періоду від 10.02.2016 № 67 [17]; від 25.05.2018 № 238 уточнені повноваження командування об'єднаних сил під час здійснення військового співробітництва [18], Порядок організації та здійснення міжнародного співробітництва Міноборони України та ЗС України від 15.12.2017 № 665; від 14.09.2018 № 469/1679 уточнена назва акту (спільного 3 MO3 України), яким визначено механізм надання медичної допомоги військовослужбовцям, які беруть участь в АТО та ООС та/або в умовах запровадження воєнного чи надзвичайного стану [19].

Верховною Радою України:

20.03.2018 ухвалено комплекс невідкладних заходів щодо практичної реалізації міжнародно-правової відповідальності РФ за збройну агресію проти України [20]. На виконання цих заходів Уряд України 12.12.2018 утворив Міжвідомчу комісію та затвердив Положення про Міжвідомчу комісію з питань узагальнення правової позиції держави щодо відсічі і стримування збройної агресії РФ та підготовки консолідованої претензії України до РФ [21]. Уряду необхідно ще розробити Методику визначення шкоди та обсягу збитків, 
завданих Україні внаслідок збройної агресії РФ; законопроект про створення Реєстру фізичних та юридичних осіб, які постраждали внаслідок збройної агресії РФ; продовжити та розширити застосування механізму ЄСПЛ щодо відповідальності РФ;

12.07.2018 прийнято Закон України «Про правовий статус осіб, зниклих безвісти» [22]. Але, у той же час, з’явилося подання 47 народних депутатів України щодо конституційності Закону, але Конституційний Суд України 20.06.2018 відмовив у відкритті конституційного провадження [23];

06.12.2018 - Закон України «Про прилеглу зону України» [24] (морська акваторія, яку сьогодні патрулюють прикордонники, збільшилась вдвічі - до 24 морських миль, а під час ООС військовослужбовці, підрозділи, кораблі та катери ДПС України мають право застосовувати і використовувати зброю та бойову техніку у випадках та порядку, передбачених законодавством України для з'єднань, військових частин та підрозділів ЗС України).

Указом Президента України від 07.02.2019 затверджено «Межі та перелік районів, міст, селищ i сіл, частин їх територій, тимчасово окупованих у Донецькій та Луганській областях» [25], який ми вважаємо прийнятим із перевищенням повноважень за відсутності реалізації процедури введення воєнного стану та наявності схожого акту Уряду [26];

10.10.2018 постановою Уряду України затверджено Порядок застосування зброї і бойової техніки з'єднаннями, військовими частинами і підрозділами Збройних Сил під час виконання ними завдань щзодо відсічі збройної агресї̈ проти України (далі - Порядок) [27]. Але який, на наш погляд, не відповідає зазначеним правовим підставам при його затвердженні (абзацам шостому, сьомому частини першої статті $1^{-1}$, абзацу восьмому ст. 9 Закону України «Про Збройні Сили України» [28]) та Закону, що аналізується.

Порядок де-юре не є правовим підзаконним механізмом в умовах ООС («деокупації» Донбасу) у контексті Закону. Його правовими підставами визначені юридичні факти, які вже відбулися та не стосуються «деокупації» тимчасово окупованих територій. Адже Порядок визначає процедуру застосування зброї за умов відсічі можливої збройної агресї проти України.

Вбачається, що логічним кроком було б завчасне внесення змін до статей $1,1^{-1}, 9$ Закону України «Про Збройні Сили України» щодо актуалізації відповідних функцій та завдань 3С України, а також відповідних повноважень Уряду стосовно ЗС України в умовах правового режиму особливого періоду, пов'язаного із агресією РФ, тимчасовою окупацією нею відповідних територій України, а також у зв’язку з прийняттям Закону, що аналізується. I вже наступним логічним кроком слід затверджувати урядовий Порядок застосування зброї і бойової техніки з'єднаннями, військовими частинами і підрозділами Збройних Сил під час виконання ними завдань щодо забезпечення національної безпеки і оборони, відсічі і стримування збройної агресї (а фактично - «завдань щзодо стримування збройної агресї та відновлення територіальної цуілісності Украӥни»). Саме така нормотворча системна логіка простежується у затверджених раніше Урядом аналогічних Порядках [29], [30], [31] як механізмах реалізації ст. 9 Закону України «Про Збройні Сили України». 


\section{3. Висновки і перспективи подальших досліджень}

У теоретико-правовій площині механізм реалізації «деокупаційного» законодавства ми розуміємо як складний структурований процес (систему), що складається із всебічно узгодженої підсистеми нижчого рівня, яка містить чотири відносно самостійних, але взаємозв'язаних обов'язкових процеси законотворчий; нормотворчий (деталізація, конкретизація); процес дії законодавчих та підзаконних нормативних приписів (виникнення правовідносин як об'єктивної форми реалізації прав і обов'язків); процес реалізації нормативних приписів (безпосередні поведінкові акти втілення дозволів, зобов'язань, заборон), а також два додаткових (факультативних) - процеси застосування та тлумачення нормативних приписів актів, зокрема загального та військового законодавства України, що діють в умовах ООС.

Здійснений аналіз Закону, нормативних актів для його реалізації частково збігаються із позицією провідних науковців у сфері безпеки і оборони держави досвід ООС показує, що наявна система стратегічного керівництва обороною держави не відповідає сучасним вимогам і стандартам НАТО [6, с. 30].

«Новели» Закону де-факто перекладають обсяг та зміст відповідальності вищих державних та військово-посадових осіб, зокрема ВГК ЗСУ та НГШ-ГК ЗСУ за можливі негативи у «деокупації» територій та проведення ООС. Адже «факт остаточного виведення та повної відсутності всіх збройних формувань РФ у Донецькій та Луганській областях встановлюється Міністром оборони України та Міністром внутрішніх справ України шляхом спільного подання Президентові України, який виключно на цій підставі приймає відповідне рішення» [1]. Вважається, що для відсічі збройній агресії необхідно введення воєнного стану на певній території, але цього не впроваджено. А для реальної відповідальності РФ за збройну агресію необхідне рішення Міжнародного кримінального суду, а не декларативні «новели» Закону про це.

Дуже важливо, що Закон де-юре та де-факто переформатував АТО в ООС, але, на жаль, не створив дієвий військово-силовий та організаційно-правовий механізм повернення тимчасово окупованих територій, не усунув, а поширив ряд колізій, протиріч та дублювань.

Верховною Радою прийнято ряд необхідних законів для реалізації Закону, але які ним не були передбачені. У той час, Закон усупереч Конституції України унормував, а Президент України вже прийняв ряд указів із перевищенням повноважень, передбачених ст. 106 Конституції України [32], у тому числі із дублюванням вже чинних актів Кабінету Міністрів України. А сам Кабінет Міністрів України не зміг привести свої нормативно-правові акти та не забезпечив приведення центральними органами виконавчої влади їх нормативно-правових актів у відповідність із Законом у встановлений строк.

Але відсіч агресії РФ не тільки і не скільки правове питання, але у першу чергу - реальне підвищення рівня воєнної безпеки держави через її обороннопромисловий комплекс, ефективність всіх складових сектору безпеки і оборони України, а також підвищення життєвого рівня, соціального статусу громадян України і держави в цілому, що перетворить процес повернення окупованих 
територій Сходу держави на більш реалістичний, добровільний, незворотньосвідомий громадянський та цивілізаційний вибір.

\title{
Пропозиції:
}

У практичній площині - в Україні необхідно негайно відновити систему військових судів та створити Військову поліцію. Відносно військової прокуратури - повинна бути тимчасово відновлена функція загального нагляду за додержанням та застосуванням законів у всіх складових сил оборони в умовах проведення ООС та під час особливого періоду з метою ефективної реалізації «деокупаційного» законодавства України.

Подальші дослідження «деокупаційного законодавства» України в умовах ООС необхідно здійснювати за окремими видами ЗС України та правовими особливостями застосування у складі об'єднаних сил міжвідомчих угрупувань військ (сил).

\section{Author details (in Russian)}

\section{Особенности реализации «деоккупационного законодательства» Украины в условиях проведения операции объединенных сил}

\author{
Владимир Шульгин *, Володимир Пашинський ** \\ * Военный институт Киевского наџионального университета имени Тараса Шевченко, \\ ул. Ломоносова, 81, г. Киев, 03022, Украина, \\ e-mail:vshulgin@ukr.net, \\ к.ю.н., \\ дочент кафедры правового обеспечения факультета финансов и права. \\ ** Национальный университет оборонь Украины имени Ивана Черняховского, \\ проспект Воздухофлотский, 28, г. Киев, 03049, \\ e-mail:vpash64@ukr.net, \\ к.ю.н., \\ доцент кафедры правового обеспечения.
}

Аннотация: В статье анализируются теоретико-правовые, законотворческие и нормотворческие аспекты эффективности юридического механизма реализации «деокупацийного законодательства» Украина особого периода. Установлено, что стартовый законодательно-нормативный блок содержит отдельные деструктивные юридические конструкции, которые способны деформировать подзаконный (военно-ведомственный) уровень процесса реализации военного законодательства Украины в условиях проведения операции объединенных сил. Предложены пути нейтрализации деструктивных (формальных, дублирующих, декларативных, коллизионных) юридических конструкций с целью оптимизации действенного, военно-силового и организационно-правового механизма возврата временно оккупированных территорий на Востоке Украины.

Ключевые слова: деокупаційне законодавство України, особливий період, операція об'єднаних сил, правовий режим операції об'єднаних сил, реалізація військового законодавства України, колізії та прогалини, прийоми законодавчої техніки, ефективність юридичних механізмів реалізації деокупаційного законодавства. 


\title{
Author details (in English)
}

\section{Features of realization of "de-occupation legislation" of Ukraine in conditions of the operation of the united forces}

\author{
Vladimir Shulgin *, Volodymyr Pashynsky ** \\ * Military Institute of Taras Shevchenko National University of Kyiv, \\ 81, Lomonosov Str., Kyiv, 03022, Ukraine, \\ e-mail:vshulgin@ukr.net, \\ Ph.D., \\ Associate Professor, Department of Legal Support, Faculty of Finance and Law. \\ ** The National Defense University of Ukraine named after Ivan Cherniakhovskyi, \\ 28, Povitroflotsky Ave., Kyiv, 03049, Ukraine, \\ e-mail:vpash64@ukr.net, \\ Ph.D., \\ Associate Professor, Department of Legal Support.
}

Abstract: The aim of the study is to provide a comprehensive analysis of the theoretical and legal, legislative and normative aspects of the effectiveness of legal mechanisms (material and procedural) for implementing the framework Law of Ukraine «On the peculiarities of state policy on ensuring the state sovereignty of Ukraine in temporarily occupied territories in the Donetsk and Luhansk oblasts» (hereinafter - the Law) and «de-occupation laws» of Ukraine (separate acts of legislation in the field of security and defense), connected with the process of implementation of the "special" normative-law the provisions of the Law in the military-defense and civil-military sphere of social relations in the temporarily occupied territories of Ukraine; development of theoretical and applied tools and methods of substantiation of ways of its improvement.

Achievement of the set goal involves solving the following tasks:

to establish the relevance of scientific research for the Armed Forces of Ukraine which, in the context of mortal danger, for the first time in its modern history as a sovereign and independent, democratic state is involved under the Law for the maintenance of national security and defense, repression and deterrence of armed aggression of the Russian Federation in the Donetsk and Luhansk oblasts;

to determine the state of development of scientific researches on the theoretical, legal, departmental normative features of the legal mechanism for implementation of the requirements of the "de-occupation legislation" of Ukraine in the conditions of the operation of the united forces;

to carry out an analysis of the methods (rules, means) of the legislative technique, the basic normative part and the complex material-procedural mechanism of implementation of the Law at the presidential, governmental, military-departmental levels of government;

to establish the state of efficiency of the rule-making block in the process of implementing the Law in conditions of operation of the united forces in the aspect of the activity of the Armed Forces of Ukraine, one year after its adoption;

outline the ways of improving the mechanism of implementation of the «occupation legislation» of Ukraine in the context of the operation of the combined forces.

Methods of research are a complex combination of philosophical, general scientific and special methods. The system method allowed to analyze the components of the rule-making block, the system of acts in the field of security and defense in the process of implementation of the Law. The formal logical method has established material procedures, structure, components of legal mechanisms of implementation, collisions and gaps. The analysis and synthesis method defines the components of the implementation process, identifies the problems, formulates the conclusions and suggestions. 
It is revealed that the initial legislative-normative block contains separate destructive legal constructions that are capable of deforming the sub-law (military-departmental) level of the process of realization of the military legislation of Ukraine in the conditions of the operation of the combined forces. The ways of neutralization of destructive (formal, duplicate, declarative, collisional) legal constructions are proposed in order to optimize the effective, military-force and organizational-legal mechanism of the return of temporarily occupied territories in the East of Ukraine.

Keywords: the de-occupation legislation of Ukraine, the special period, the operation of the united forces, the legal regime of the operation of the united forces, the realization of the military legislation of Ukraine, the conflicts and gaps, the techniques of legislative technique, the effectiveness of the legal mechanisms for the realization of the de-occupation law.

\section{Використана література}

1. Про особливості державної політики із забезпечення державного суверенітету України на тимчасово окупованих територіях у Донецькій та Луганській областях: Закон України від 18.01.2018 № 2268-VIII. Відомості Верховної Ради Украӥни. 2018. № 10. Ст. 54.

2. Агапова О.В. Адміністративно-правові засади діяльності Національної гвардії України: дис. ... канд. юрид. наук. Харків, 2017. 244 с.

3. Коропатнік I.M. Взаємодія громадянського суспільства i Збройних Сил України: адміністративно-правові засади: моногр. К.: «МП Леся», 2016. 412 с.

4. Пашинський В. Й. Адміністративно-правове забезпечення діяльності Збройних Сил України. Право та державне управління. 2018. № 3 (32). Том 1. С. 62-67.

5. Біла книга антитерористичної операції на Сході України (2014-2016) / заг. ред. І. Руснака. К.: НУО України імені Івана Черняховського, 2017. 162 с.

6. Сектор безпеки і оборони України: стратегічне керівництво та військове управління: монографія / Саганюк Ф.В., Фролов В.С., Павленко В.І. та ін.; за ред. І.С. Руснака. К.: ЦЗ МО та ГШ ЗС України, 2018. 230 с.

7. Сокуренко В.В. Оборона як ефективний засіб забезпечення безпеки суспільства та держави. Адміністративне право і прочес. 2017. № 2. С. 159-166.

8. Греков А. Правовое положение армии в государстве: Опыт исследования правовых оснований жизни армии в главнейших государствах современной Европы. С.-Пб.: В. Березовский, 1908. 244 с.

9. Бобров Ю. АТО у операції об'єднаних сил триватимуть паралельно / URL: https://novynarnia.com/2018/04/27/.

10. URL: https://www.ukrinform.ua/rubric-ato/2417100.

11. Головний військовий прокурор України Анатолій Матіос: «На війні закон має бути в погонах» / URL: http://mediarnbo.org/2018/05/19/.

12. URL: https://ua.interfax.com.ua/news/interview/555969.

13. Про рішення Ради національної безпеки і оборони України від 02.05.2018 «Про припинення дії для України окремих міжнародних договорів, укладених у рамках Співдружності Незалежних Держав»: Указ Президента України від 19.05.2018 № 139/2018. Офіиійний вісник Президента Украӥни. 2018. № 13. Ст. 211.

14. Положення про групу юридичного радника Об'єднаного командного пункту Об'єднаних сил: Наказ Командувача об’єднаними силами від 22.04.2018 № 18-дск. //Архів ООШ ЗС України за 2018 рік.

15. Про доведення особливого порядку, що діятиме у зонах безпеки та районі бойових дій із оголошенням Верховним Головнокомандувачем 3С України рішення про початок проведення операції об'єднаних сил: Розпорядження Об'єднаного оперативного штабу Збройних Сил України від 26.04.2018 № 313/ОКПОС/127. // Архів військової частини A0135 II. м. Краматорськ, Донецької області. 2018.

16. Про початок операції Об'єднаних сил із забезпечення національної безпеки і оборони, відсічі та стримування збройної агресії Російської Федерації на території Донецької та 
Луганської областей: Наказ Верховного Головнокомандувача Збройних Сил України від 30.04.2018 № 3дск-оп / URL: http://www.president.gov.ua/news/30-kvitnya-rozpochalasoperaciya-obyednanih-sil-iz-vidsichi-47206.

17. Інструкція про розміри і порядок виплати винагороди військовослужбовцям Збройних Сил України та Державної спеціальної служби транспорту за безпосередню участь у воєнних конфліктах, в заходах із забезпечення національної безпеки i оборони, відсічі i стримування збройної агресії Російської Федерації чи в антитерористичній операції, інших заходах в умовах особливого періоду: Наказ Міністерства оборони України від 10.02.2016 № 67 в редакції Наказу Міністерства оборони № 268 від 12.06.2018. Офіиійний вісник України. 2018. № 55. Ст. 1940.

18. Про затвердження змін до наказу Міністерства оборони України від 15.12.2017 № 665: Наказ Міністерства оборони України від 25.05.2018 № 238 / URL: http://www.mil.gov.ua/content/mou_orders/238_nm_2018.pdf.

19. Про визначення механізму надання вторинної (спеціалізованої) і третинної (високоспеціалізованої) медичної допомоги військовослужбовцям, які беруть участь в антитерористичній операції та здійсненні заходів із забезпечення національної безпеки і оборони, відсічі і стримування збройної агресії Російської Федерації та/або в умовах запровадження воєнного чи надзвичайного стану: Наказ Міністерства оборони України та Міністерства охорони здоров'я України в редакції наказу Міноборони України від 14.09.2018 № 469/1679. Офіиійний вісник Украӥни. 2018. № 84. Ст. 229.

20. Про комплекс невідкладних заходів щодо практичної реалізації міжнародно-правової відповідальності Російської Федерації за збройну агресію проти України: Постанова Верховної Ради України від 20.03.2018 № 2356-VIII. Голос Украӥни. 2018 № 63.

21. Положення про Міжвідомчу комісію з питань узагальнення правової позиції держави щодо відсічі і стримування збройної агресії РФ та підготовки консолідованої претензії України до РФ щодо реалізації ії міжнародно-правової відповідальності за збройну агресію проти України: Постанова Кабінету Міністрів України від 12.12.2018 № 1059. Урядовий кур’єр. 2018. № 239.

22. Про правовий статус осіб, зниклих безвісти: Закон України від 12.07.2018 № 2505-VIII. Відомості Верховної Ради. 2018. № 38. Ст. 280.

23. Про відмову у відкритті конституційного провадження у справі за конституційним поданням 47 народних депутатів України щодо відповідності Конституції України (конституційності) Закону України «Про особливості державної політики із забезпечення державного суверенітету України на тимчасово окупованих територіях у Донецькій та Луганській областях»: Ухвала Великої Палати Конституційного Суду України від 20.06.2018 № 40-y/2018 / URL: https://zakon.rada.gov.ua/laws/show/v040u71018

24. Про прилеглу зону України: Закон України від 06.12.2018 № 2641-VIII. Голос Украӥни. 03.01.2019. № 1 .

25. Про межі та перелік районів, міст, селищ і сіл, частин їх територій, тимчасово окупованих у Донецькій та Луганській областях: Указ Президента України від 07.02.2019 № 32/2019. Урядовий кур’єр. 09.02.2019 № 27.

26. Про затвердження переліку населених пунктів, на території яких органи державної влади тимчасово не здійснюють свої повноваження, та переліку населених пунктів, що розташовані на лінії зіткнення: Розпорядження Кабінету Міністрів України від 07.11.2014 № 1085-р. Урядовий кур’'єр. 15.11.2014 № 213.

27. Порядок застосування зброї і бойової техніки з'єднаннями, військовими частинами i підрозділами Збройних Сил під час виконання ними завдань щодо відсічі збройної агресії проти України: Постанова Кабінету Міністрів України від 10.10.2018 № 828. Офіиійний вісник України. 2018. № 82. Ст. 2724.

28. Про Збройні Сили України: Закон України від 06.12.1991 № 1934-XII. Відомості Верховної Ради України. 1992. № 9. Ст. 108. 
29. Порядок застосування зброї і бойової техніки з'єднаннями, військовими частинами i підрозділами Військово-Морських Сил Збройних Сил в мирний час у разі виконання ними завдань з охорони підводного простору в межах територіального моря України: Постанова Кабінету Міністрів України від 19.11.2008 № 1007. Офіиійний вісник України. 2008. № 89. Ст. 2981.

30. Порядок застосування (використання) зброї і бойової техніки з'єднаннями, військовими частинами і підрозділами Збройних Сил під час виконання ними завдань боротьби 3 піратством: Постанова Кабінету Міністрів України від 11.07.2013 № 487. Офіиійний вісник України. 2013. № 53. Ст. 1938.

31. Порядок застосування зброї і бойової техніки з'єднаннями, військовими частинами i підрозділами Збройних Сил під час виконання ними завдань у районі проведення антитерористичної операції у мирний час: Постанова Кабінету Міністрів України від 14.02.2018 № 68. Офічійний вісник України. 2018. № 18. Ст. 602.

32. Рішення Конституційного Суду України від 16.05.2007 № 1-рп/2007. Офімійний вісник Украӥни. 2007. № 48. Ст. 1992.

\section{References}

1. Verkhovna Rada Ukrainy (2018). Pro osoblyvosti derzhavnoi polityky iz zabezpechennia derzhavnoho suverenitetu Ukrainy na tymchasovo okupovanykh terytoriiakh u Donetskii ta Luhanskii oblastiakh: Zakon Ukrainy vid 18.01.2018 № 2268-VIII [On peculiarities of state policy on ensuring state sovereignty of Ukraine in temporarily occupied territories in Donetsk and Luhansk oblasts: Law of Ukraine dated January 18, 2018, n. 2268-VIII]. Vidomosti Verkhovnoi Rady Ukrainy [Supreme Council of Ukraine], 2018, n. 10, Art. 54 (in Ukrainian).

2. Ahapova O.V. (2017). Administratyvno-pravovi zasady diialnosti Natsionalnoi hvardii Ukrainy [Administrative and legal principles of the activity of the National Guard of Ukraine]. Thesis for a Candidate of Law. Kharkiv, 244 p. (in Ukrainian).

3. Koropatnik I.M. (2016). Vzaiemodiia hromadianskoho suspilstva i Zbroinykh Syl Ukrainy: administratyvno-pravovi zasady [Interaction of civil society and the Armed Forces of Ukraine: administrative and legal principles]. Monohrafiia [Monograph]. Kiev, MP Lesya, 412 p. (in Ukrainian).

4. Pashynskyi V.I. (2018). Administratyvno-pravove zabezpechennia diialnosti Zbroinykh Syl Ukrainy [Administrative and legal support of the activity of the Armed Forces of Ukraine]. Pravo ta derzhavne upravlinnia [Law and public administration], n. 3, Volume 1, p. 62-63 (in Ukrainian).

5. Rusnak I.S. (Ed.). (2017). Bila knyha antyterorystychnoi operatsii na Skhodi Ukrainy (2014-2016) [White Paper on Anti-Terrorist Operation in the East of Ukraine (2014-2016)] Natsionalnyi universytet oborony Ukrainy imeni Ivana Cherniakhovskoho [National University of Defense of Ukraine named after Ivan Cherniakhovsky], Kiev, 162 p. (in Ukrainian).

6. Rusnak I.S. (Ed.). (2018). Sektor bezpeky i oborony Ukrainy: stratehichne kerivnytstvo ta viiskove upravlinnia [The Ukrainian Security and Defense Sector: Strategic Leadership and Military Management]. Monohrafiia [Monograph]. Kiev, Center for Defense of the Ministry of Defense and General Staff of the Armed Forces of Ukraine, 230 p. (in Ukrainian).

7. Sokurenko V.V. (2017). Oborona yak efektyvnyi zasib zabezpechennia bezpeky suspilstva ta derzhavy [Defense as an effective means of ensuring the security of society and the state]. Administratyvne pravo i protses [Administrative law and process], n. 2, p. 159-166 (in Ukrainian).

8. Hrekov A. (1908). Pravovoye polozheniye armii v gosudarstve: Opyt issledovaniya pravovykh osnovaniy zhizni armii v glavneyshikh gosudarstvakh sovremennoy Yevropy [The legal status of the army in the state: Experience in the study of the legal basis of the life of the army in the main states of modern Europe]. St. Petersburg, V. Berezovsky, 244 p. 
9. Bobrov Yu. (2018). Antyterorystychna operatsiia u operatsii obiednanykh syl tryvatymut paralelno [The anti-terrorist operation in the operation of the combined forces will continue in parallel]. / URL: https://novynarnia.com/2018/04/27/_(in Ukrainian).

10. URL: https://www.ukrinform.ua/rubric-ato/2417100_(in Ukrainian).

11. Anatolii Matios (2018). "Na viini zakon maie buty v pohonakh" ["In the war, the law should be in uniform"]. / URL: http://mediarnbo.org/2018/05/19/_(in Ukrainian).

12. URL: https://ua.interfax.com.ua/news/interview/555969 (in Ukrainian).

13. Prezydent Ukrainy (2018). Pro rishennia Rady natsionalnoi bezpeky i oborony Ukrainy vid 02.05.2018 "Pro prypynennia dii dlia Ukrainy okremykh mizhnarodnykh dohovoriv, ukladenykh u ramkakh Spivdruzhnosti Nezalezhnykh Derzhav": Ukaz Prezydenta Ukrainy vid 19.05.2018 № 139/2018 [On the decision of the Council of National Security and Defense of Ukraine from 19.05.2018 "On termination of certain international treaties concluded by Ukraine within the framework of the Commonwealth of Independent States" for Ukraine: Decree of the President of Ukraine dated May 19, 2018, n. 139/2018]. Ofitsiinyi visnyk Ukrainy [The official Bulletin of Ukraine], 2018, n. 13, Art. 211 (in Ukrainian).

14. Komanduvach obiednanymy sylamy (2018). Polozhennia pro hrupu yurydychnoho radnyka Obiednanoho komandnoho punktu Obiednanykh syl: Nakaz Komanduvacha obiednanymy sylamy vid 22.04.2018 № 18-dsk [Provision on the group of legal adviser of the Joint Command Element of the Joint Forces: Order of the Commander of the Joint Forces dated April 22, 2018, n. 18-fou]. Arkhiv Obiednanoho operatyvnoho shtabu Zbroinykh Syl Ukrainy [Archive of the Joint Operational Headquarters of the Armed Forces of Ukraine], 2018 (in Ukrainian).

15. Obiednanyi operatyvnyi shtab Zbroinykh Syl Ukrainy (2018). Pro dovedennia osoblyvoho poriadku, shcho diiatyme u zonakh bezpeky ta raioni boiovykh dii iz oholoshenniam Verkhovnym Holovnokomanduvachem Zbroinykh Syl Ukrainy rishennia pro pochatok provedennia operatsii obiednanykh syl: Rozporiadzhennia Obiednanoho operatyvnoho shtabu Zbroinykh Syl Ukrainy vid 26.04.2018 № 313/OKPOS/127 [On the bringing of a special order in the security zones and area of fighting with the declaration of the Supreme Commander-inChief of the Armed Forces of Ukraine on the decision to start the operation of the united forces: The Order of the Joint Operational Headquarters of the Armed Forces of Ukraine dated April 26, 2018, n. 313/JCPJF/127]. Arkhiv viiskovoi chastyny A0135 II. m. Kramatorsk, Donetskoi oblasti [Archive of military unit A0135 II. Kramatorsk, Donetsk region], 2018 (in Ukrainian).

16. Verkhovnyi Holovnokomanduvach Zbroinykh Syl Ukrainy (2018). Pro pochatok operatsii Obiednanykh syl iz zabezpechennia natsionalnoi bezpeky i oborony, vidsichi ta strymuvannia zbroinoi ahresii Rosiiskoi Federatsii na terytorii Donetskoi ta Luhanskoi oblastei: Nakaz Verkhovnoho Holovnokomanduvacha Zbroinykh Syl Ukrainy vid 30.04.2018 № 3dsk-op [On the commencement of the operation of the Joint Forces for the National Security and Defense, repression and deterrence of the armed aggression of the Russian Federation in the territory of Donetsk and Luhansk Oblasts: Order of the Supreme Commander-in-Chief of the Armed Forces of Ukraine dated April 30, 2018, n. 3fou-sp]. /URL: http://www.president.gov.ua/news (in Ukrainian).

17. Ministerstvo oborony Ukrayiny (2018). Instruktsiia pro rozmiry i poriadok vyplaty vynahorody viiskovosluzhbovtsiam Zbroinykh Syl Ukrainy ta Derzhavnoi spetsialnoi sluzhby transportu za bezposeredniu uchast $\mathrm{u}$ voiennykh konfliktakh, $\mathrm{v}$ zakhodakh iz zabezpechennia natsionalnoi bezpeky i oborony, vidsichi i strymuvannia zbroinoi ahresii Rosiiskoi Federatsii chy v antyterorystychnii operatsii, inshykh zakhodakh $\mathrm{v}$ umovakh osoblyvoho periodu: Nakaz Ministerstva oborony Ukrainy vid 12.06.2018 № 268 [Instruction on the size and procedure for payment of remuneration to servicemen of the Armed Forces of Ukraine and the State Special Transport Service for their direct participation in military conflicts, in measures for ensuring national security and defense, repression and deterrence of armed aggression in the Russian Federation or in a counter-terrorist operation, and other measures in a special period : Order of the Ministry of Defense of Ukraine dated June 12, 2018, n. 268]. Ofitsiinyi visnyk Ukrainy [The official Bulletin of Ukraine], 2018, n. 55, Art. 1940 (in Ukrainian). 
18. Ministerstvo oborony Ukrayiny (2018). Pro zatverdzhennia zmin do nakazu Ministerstva oborony Ukrainy vid 15.12.2017 № 665: Nakaz Ministerstva oborony Ukrainy vid 25.05.2018 № 238 [On Approval of Amendments to the Order of the Ministry of Defense of Ukraine dated 15.12.2017, n. 665: Order of the Ministry of Defense of Ukraine dated May 25, 2018, n. 238]. /URL: http://www.mil.gov.ua/content/mou_orders/238_nm_2018.pdf (in Ukrainian).

19. Ministerstvo oborony Ukrayiny (2018). Pro vyznachennia mekhanizmu nadannia vtorynnoi (spetsializovanoi) i tretynnoi (vysokospetsializovanoi) medychnoi dopomohy viiskovosluzhbovtsiam, yaki berut uchast $\mathrm{v}$ antyterorystychnii operatsii ta zdiisnenni zakhodiv iz zabezpechennia natsionalnoi bezpeky i oborony, vidsichi i strymuvannia zbroinoi ahresii Rosiiskoi Federatsii ta/abo v umovakh zaprovadzhennia voiennoho chy nadzvychainoho stanu: Nakaz Ministerstva oborony Ukrainy ta Ministerstva okhorony zdorovia Ukrainy vid 14.09.2018 № 469/1679 [On the definition of the mechanism for the provision of secondary (specialized) and tertiary (highly specialized) medical assistance to servicemen who participate in the anti-terrorist operation and to take measures to ensure national security and defense, repression and deterrence of armed aggression of the Russian Federation and / or in the event of the introduction of a martial or emergency state : Order of the Ministry of Defense of Ukraine and the Ministry of Health of Ukraine dated September 14, 2018, n. 469/1679]. Ofitsiinyi visnyk Ukrainy [The official Bulletin of Ukraine], 2018, n. 84, Art. 229 (in Ukrainian).

20. Verkhovna Rada Ukrainy (2018). Pro kompleks nevidkladnykh zakhodiv shchodo praktychnoi realizatsii mizhnarodno-pravovoi vidpovidalnosti Rosiiskoi Federatsii za zbroinu ahresiiu proty Ukrainy: Postanova Verkhovnoi Rady Ukrainy vid 20.03.2018 № 2356-VIII [On the complex of urgent measures concerning the practical implementation of the international legal responsibility of the Russian Federation for armed aggression against Ukraine: Resolution of the Verkhovna Rada of Ukraine dated March 20, 2018, n. 2356-VIII]. Holos Ukrainy [The Voice of Ukraine], 2018, n. 63. (in Ukrainian).

21. Cabinet of Ministers of Ukraine (2018). Polozhennia pro Mizhvidomchu komisiiu z pytan uzahalnennia pravovoi pozytsii derzhavy shchodo vidsichi i strymuvannia zbroinoi ahresii Rosiiskoi Federatsii ta pidhotovky konsolidovanoi pretenzii Ukrainy do RF shchodo realizatsii yii mizhnarodno-pravovoi vidpovidalnosti za zbroinu ahresiiu proty Ukrainy: Postanova Kabinetu Ministriv Ukrainy vid 12.12.2018 № 1059 [Regulation on the Interdepartmental Commission on the generalization of the legal position of the state regarding the suppression and deterrence of armed aggression of the Russian Federation and the preparation of a consolidated claim of Ukraine to the Russian Federation regarding the implementation of its international legal responsibility for armed aggression against Ukraine: Resolution of the Cabinet of Ministers of Ukraine dated December 12, 2018, n. 1059]. Uriadovyi kurier [Government courier], 2018, n. 239 (in Ukrainian).

22. Verkhovna Rada Ukrainy (2018). Pro pravovyi status osib, znyklykh bezvisty: Zakon Ukrainy vid 12.07.2018 № 2505-VIII [On the legal status of missing persons: Law of Ukraine dated July 12, 2018, n. 2505-VIII]. Vidomosti Verkhovnoi Rady Ukrainy [Supreme Council of Ukraine], 2018, n. 38, Art. 280 (in Ukrainian).

23. Konstytutsiinyi Sud Ukrainy (2018). Pro vidmovu u vidkrytti konstytutsiinoho provadzhennia u spravi za konstytutsiinym podanniam 47 narodnykh deputativ Ukrainy shchodo vidpovidnosti Konstytutsii Ukrainy (konstytutsiinosti) Zakonu Ukrainy "Pro osoblyvosti derzhavnoi polityky iz zabezpechennia derzhavnoho suverenitetu Ukrainy na tymchasovo okupovanykh terytoriiakh u Donetskii ta Luhanskii oblastiakh": Ukhvala Velykoi Palaty Konstytutsiinoho Sudu Ukrainy vid 20.06.2018 № 40-u/2018 [On refusal to open constitutional proceedings in a case under the constitutional petition of 47 people's deputies of Ukraine regarding the compliance of the Constitution of Ukraine (constitutionality) with the Law of Ukraine "On the peculiarities of state policy on ensuring the state sovereignty of Ukraine in temporarily occupied territories in the Donetsk and Luhansk oblasts": Decision of the Grand Chamber of the Constitutional Court Ukraine dated June 20, 2018, n. 40-u/2018]. /URL: https://zakon.rada.gov.ua/laws/ show/v040u710-18 (in Ukrainian). 
24. Verkhovna Rada Ukrainy (2018). Pro prylehlu zonu Ukrainy: Zakon Ukrainy vid 06.12.2018 № 2641-VIII [On the adjacent zone of Ukraine: Law of Ukraine dated December 6, 2018, n. 2641 VIII]. Holos Ukrainy [The Voice of Ukraine], 03.01.2019, n. 1 (in Ukrainian).

25. Prezydent Ukrainy (2019). Pro mezhi ta perelik raioniv, mist, selyshch i sil, chastyn yikh terytorii, tymchasovo okupovanykh u Donetskii ta Luhanskii oblastiakh: Ukaz Prezydenta Ukrainy vid 07.02.2019 № 32/2019 [On the boundaries and list of districts, cities, villages and villages, parts of their territories temporarily occupied in Donetsk and Luhansk oblasts: Decree of the President of Ukraine dated February 7, 2019, n. 32/2019]. Uriadovyi kurier [Government courier], 2019, n. 27 (in Ukrainian).

26. Cabinet of Ministers of Ukraine (2014). Pro zatverdzhennia pereliku naselenykh punktiv, na terytorii yakykh orhany derzhavnoi vlady tymchasovo ne zdiisniuiut svoi povnovazhennia, ta pereliku naselenykh punktiv, shcho roztashovani na linii zitknennia: Rozporiadzhennia Kabinetu Ministriv Ukrainy vid 07.11.2014 № 1085-r [On approval of the list of settlements in the territory of which the state authorities temporarily do not exercise their powers and the list of settlements located on the line of collision: The Order of the Cabinet of Ministers of Ukraine dated November 7, 2014, n. 1085-r]. Uriadovyi kurier [Government courier], 2014, n. 213 (in Ukrainian).

27. Cabinet of Ministers of Ukraine (2018). Poriadok zastosuvannia zbroi i boiovoi tekhniky ziednanniamy, viiskovymy chastynamy i pidrozdilamy Zbroinykh Syl pid chas vykonannia nymy zavdan shchodo vidsichi zbroinoi ahresii proty Ukrainy: Postanova Kabinetu Ministriv Ukrainy vid 10.10.2018 № 828 [The procedure for the use of weapons and military equipment by units, military units and units of the Armed Forces while carrying out their tasks for the repression of armed aggression against Ukraine: Resolution of the Cabinet of Ministers of Ukraine dated October 10, 2018, n. 828]. Ofitsiinyi visnyk Ukrainy [The official Bulletin of Ukraine], 2018, n. 82, Art. 2724 (in Ukrainian).

28. Verkhovna Rada Ukrainy (1992). Pro Zbroini Syly Ukrainy: Zakon Ukrainy vid 06.12.1991 № 1934-XII [On the Armed Forces of Ukraine: Law of Ukraine dated December 6, 1991, n. 1934XII]. Vidomosti Verkhovnoi Rady Ukrainy [Supreme Council of Ukraine], 1992, n. 9, Art. 108 (in Ukrainian).

29. Cabinet of Ministers of Ukraine (2008). Poriadok zastosuvannia zbroi i boiovoi tekhniky ziednanniamy, viiskovymy chastynamy i pidrozdilamy Viiskovo-Morskykh Syl Zbroinykh Syl $\mathrm{v}$ myrnyi chas $\mathrm{u}$ razi vykonannia nymy zavdan $\mathrm{z}$ okhorony pidvodnoho prostoru $\mathrm{v}$ mezhakh terytorialnoho moria Ukrainy: Postanova Kabinetu Ministriv Ukrainy vid 19.11.2008 № 1007 [The procedure for the use of weapons and military equipment by units, military units and units of the Naval Forces of the Armed Forces in peacetime in the event that they perform tasks concerning the protection of the underwater space within the territorial sea of Ukraine: Resolution of the Cabinet of Ministers of Ukraine dated November 19, 2008, n. 1007]. Ofitsiinyi visnyk Ukrainy [The official Bulletin of Ukraine], 2008, n. 89, Art. 2981 (in Ukrainian).

30. Cabinet of Ministers of Ukraine (2013). Poriadok zastosuvannia (vykorystannia) zbroi i boiovoi tekhniky ziednanniamy, viiskovymy chastynamy i pidrozdilamy Zbroinykh Syl pid chas vykonannia nymy zavdan borotby z piratstvom: Postanova Kabinetu Ministriv Ukrainy vid 11.07.2013 № 487 [The procedure for the use (use) of weapons and military equipment by units, military units and units of the Armed Forces while performing their tasks of combating piracy: Resolution of the Cabinet of Ministers of Ukraine dated July 11, 2013, n. 487]. Ofitsiinyi visnyk Ukrainy [The official Bulletin of Ukraine], 2013, n. 53, Art. 1938 (in Ukrainian).

31. Cabinet of Ministers of Ukraine (2018). Poriadok zastosuvannia zbroi i boiovoi tekhniky ziednanniamy, viiskovymy chastynamy i pidrozdilamy Zbroinykh Syl pid chas vykonannia nymy zavdan u raioni provedennia antyterorystychnoi operatsii u myrnyi chas: Postanova Kabinetu Ministriv Ukrainy vid 14.02.2018 № 68 [The procedure for the use of weapons and military equipment by units, military units and units of the Armed Forces during the execution of their tasks in the area of conducting an anti-terrorist operation in peacetime: Resolution of 
the Cabinet of Ministers of Ukraine dated February 14, 2018, n. 68]. Ofitsiinyi visnyk Ukrainy [The official Bulletin of Ukraine], 2018, n. 18, Art. 602 (in Ukrainian).

32. Konstytutsiinyi Sud Ukrainy (2007). Rishennia Konstytutsiinoho Sudu Ukrainy vid 16.05.2007 № 1-rp/2007 [Decision of the Constitutional Court of Ukraine dated May 16, 2007, n. 1rp/2007]. Ofitsiinyi visnyk Ukrainy [The official Bulletin of Ukraine], 2007, n. 48, Art. 1992 (in Ukrainian).

\section{Список умовних скорочень:}

АР Крим - Автономна Республіка Крим

АТО - антитерористична операція

ВГК ЗС України - Верховний Головнокомандувач Збройних Сил України

ВНЗ - вищі навчальні заклади

Генштаб - Генеральний штаб Збройних Сил України

ДПС України - Державна прикордонна служба України

ДССТ - Державна спеціальна служба транспорту Міністерства оборони України

ЄСПЛ - Свропейський Суд з прав людини

Закон - Закон України «Про особливості державної політики із забезпечення державного суверенітету України на тимчасово окупованих територіях у Донецькій та Луганській областях»

МГП - Міжнародне гуманітарне право

Міноборони - Міністерство оборони України

МОЗ України - Міністерство охорони здоров’я України

НГШ-ГК ЗС України - начальник Генерального штабу - Головнокомандувач Збройних Сил України

ОКПОС - Об’єднаний командний пункт об'єднаних сил

ООС - операція об'єднаних сил

ООШ - Об'єднаний оперативний штаб Збройних Сил України

Порядок - Порядок застосування зброї і бойової техніки з'єднаннями, військовими частинами і підрозділами Збройних Сил під час виконання ними завдань щодо відсічі збройної агресії проти України 